\title{
ANALISIS TREND DAN FAKTOR-FAKTOR YANG MEMPENGARUHI PRODUKSI GULA DI PG. WRINGIN ANOM KABUPATEN SITUBONDO
}

\section{TREND ANALYSIS AND THE FACTORS INFLUENCING SUGAR PRODUCTION IN WRINGIN ANOM SUGAR FACTORY SITUBONDO REGENCY}

\author{
Handa Aprisco ${ }^{1)}$, Fefi Nurdiana Wijayanti ${ }^{1)}$ dan Teguh Hari Santosa ${ }^{1)}$ \\ 1) Program Studi Agribisnis, Fakultas Pertanian, Universitas Muhammadiyah Jember \\ handa_aprisco@yahoo.com
}

\begin{abstract}
ABSTRAK
Pabrik gula merupakan pelaku agribisnis pengolah tanaman tebu dan salah satu sektor yang berperanan penting dalam industri pergulaan di Indonesia. Penelitian ini bertujuan untuk: (1) mengetahui trend luas lahan tebu, produksi dan produktivitas gula di PG. Wringin Anom Kabupaten Situbondo, (2) mengidentifikasi faktor-faktor yang mempengaruhi produksi gula di PG. Wringin Anom Kabupaten Situbondo dan (3) mengukur tingkat efisiensi biaya di PG. Wringin Anom Kabupaten Situbondo. Data dianalisis dengan analisis trend, analisis Cobb-Douglas (uji-t, uji-F, uji Adjusted $R^{2}$ ) dan analisis RC-Ratio. Hasil penelitian menunjukkan bahwa: (1) trend luas lahan tebu, produksi dan produktivitas gula di PG. Wringin Anom Kabupaten Situbondo dari tahun 2001-2015 memiliki kecenderunagn meningkat; (2) faktor-faktor yang mempengaruhi produksi gula secara signifikan adalah bobot tebu, rendemen dan tenaga kerja. (3) Penggunaan biaya di PG. Wringin Anom Kabupaten Situbondo menunjukkan tingkat efisien antara tahun 2010-2015 kecuali pada tahun 2010 dan 2013 mengalami inefisiensi biaya.
\end{abstract}

Kata kunci: Efisiensi, Gula, Produksi, Produktivitas,dan Trend.

\begin{abstract}
Sugar factory is a plantation-based agroindustry. Sugar factory as an agribusiness sugarcane processor and one of production sector has important role in Indonesia and nowadays it got many attention. Therefore, this research was conducted in Sugar Factory Wringin Anom at Situbondo Regency and purposed to: (1) know trend of sugarcane plantation area, sugar production and productivity , (2) identify the factors influencing the sugar production, and (3)measure the cost efficiency. Data were analyzed by a trend analysis, Cobb-Douglass analysis ( $t$ test, F-test, Adjusted $R^{2}$ test) and RC-ratio analysis. The research showed that: (1) Sugar cane plantation area,sugar production and productivity in Wringin Anom Sugar Factory Situbondo Regency from 2001 to 2015 had been increasing positively. (2) Significant factors that influence sugar production was the weight of sugar cane, rendemen or sucrose content of sugarcane and labour. (3) Using of cost in Wringin Anom Sugar Factory at Situbondo Regency was efficient from 2010-2015 except in 2010 and 2013 was inefficiency.
\end{abstract}

Keywords: Efficiency, , Production, Productivity, Sugar, and Trend

\section{PENDAHULUAN}

Tebu merupakan salah satu komoditi perkebunan tanaman semusim yang penting dalam pembangunan subsektor perkebunan di Jawa Timur antara lain untuk memenuhi kebutuhan gula domestik maupun ekspor

$$
\begin{aligned}
& \text { penghasil devisa negara, sehingga dalam } \\
& \text { upaya meningkatkan produksi dan } \\
& \text { produktivitas tebu serta mendukung } \\
& \text { keberhasilan program Swasembada Gula } \\
& \text { Nasional, di Jawa Timur dilaksanakan } \\
& \text { program Akselerasi Peningkatan }
\end{aligned}
$$


Produktivitas Gula Nasional sejak tahun 2001

(Disbun Jatim, 2011).

Pabrik gula sebagai agroindustri merupakan subsistem inti dari sistem agroindustri pergulaan. Sebagai industri hilir maka kaitan ke belakang cukup tinggi, mempunyai multiplier effect yang cukup kuat di pedesaan, di dalam suatu wilayah, padat karya dan padat modal, oleh karena itu kebijaksanaan yang tepat sangat menentukan dalam perkembangannya (Hafsah, 2002).Menurut Suwandi (2015), kondisi agroindustri gula sejak beberapa tahun terakhir seperti pasien kritis di instalasi gawat darurat sebuah rumah sakit kuno saat sedang terjadi peperangan yang hanya mendapatkan asupan makanan dan infus seadanya. Agroindustri gula tersandera harga jual produk yang lebih rendah dibanding biaya produksi sehingga tidak berdaya menghadapi perkembangan terkini. Peningkatan produktivitas relatif lamban, jauh di belakang biaya produksi. Agroindustri gula juga belum dapat menepis anggapan bahwa profitabilitas hanya diperoleh dari kombinasi dukungan agroklimat dan harga karena tebu pasti dipengaruhi agroklimat meskipun teknologi dapat meminimalkan resiko sedangkan pendapatan berbanding lurus dengan produksi dan harga yang berarti harga murah berisiko mempengaruhi daya tahan keberlanjutan perusahaan.

Kabupaten Situbondo sangat potensial dengan produksi tanaman tebu yang tinggi didukung dengan beberapa pabrik pengolah tebu menjadi gula, yaitu: PG. Wringin Anom, PG. Olean, PG. Pandji, dan PG. Asembagoes.
Salah satu agroindustri gula di Kabupaten Situbondo adalah Pabrik Gula Wringin Anom. PG. Wringin Anom didirikan pada tahun 1881 merupakan pabrik gula yang termasuk dalam unit usaha PT. Perkebunan Nusantara XI beserta tiga pabrik gula lainnya. Pabrik gula ini terletak di Desa Wringin Anom, Kecamatan Panarukan, Kabupaten Situbondo, Provinsi Jawa Timur.

Produksi gula pada PG. Wringin Anom setiap tahun mengalami fluktuasi yang disebabkan oleh berbagai hal terutama karena kerusakan alat di pabrik dan keterlambatan pasokan bahan baku tebu dan faktor lainnya seperti cuaca sehingga memperlambat proses produksi. Kondisi ini dapat mempengaruhi efisiensi pabrik karena jumlah biaya yang tidak seimbang dengan jumlah penerimaan. Biaya produksi termasuk biaya perawatan mesin giling tebu yang usianya sudah tua karena sebagian besar mesin di PG. Wringin Anom masih asli peninggalan Belanda dengan teknologi mesin uap, dibanding ketiga pabrik gula lainnya di Kabupaten Situbondo yang sudah menggunakan teknologi mesin giling yang sudah dimodernisasi.

Berdasar permasalahan tersebut maka penelitian ini bertujuan untuk: mengetahuitrend luas lahan tebu, produksi dan produktivitas gula di PG. Wringin Anom Kabupaten Situbondo; (2) mengidentifikasi faktor-faktor yang berpengaruh terhadap produksi gula di PG. Wringin Anom Kabupaten Situbondo; dan (3) mengukur tingkateffisiensi penggunaan biaya di PG. Wringin Anom Kabupaten Situbondo. 


\section{METODE PENELITIAN}

\section{Metode dan Lokasi Penelitian}

Metode yang digunakan dalam penelitian ini adalah metode deskriptif dan korelasional (Nazir, 1999). $\quad$ Lokasi

penelitian ini dilakukan secara sengaja(purposive methods) di Pabrik Gula Wringin Anom Kabupaten Situbondo. Dasar pertimbangannya adalah berkembangnya isu bahwa pabrik ini akan ditutup kegiatan operasionalnya karena dianggaptidaklagimenguntungkan, akan tetapi hingga saat ini pabrik masih beroperasi pada saat banyak pabrik gula yang sudah tutup.

\section{Metode Analisis Data}

Data yang digunakan dalam penelitian adalah data sekunderpada rentang waktu tahun 2001-2015.Untuk menguji hipotesis pertama yang menyatakan bahwa perkembangan luas lahan tebu, produksi dan produktivitas gula di PG. Wringin Anom Kabupaten Situbondo cenderung menurun digunakan analisis trend yaitu metode kuadrat terkecil (least square method) ). Metode ini untuk melihat perkembangan dari data deret waktu. Sebagai sampel adalah tahun produksi yang apabila jumlah data adalah genap, maka skor waktunya adalah...$5,-3,-1,1,3,5, \ldots$ Jika jumlah data adalah ganjil maka skor waktunya adalah...-2,-1,0,1,2,... persamaan trend linear yang digunakan untuk memproyeksikan hasil produksi adalah sebagai berikut (Supranto, 2011).

$$
\mathrm{Y}=\mathrm{a}+\mathrm{b} \mathrm{X}, \mathrm{a}=\frac{\sum \mathrm{y}}{\mathrm{n}}, \text { dan } \mathrm{b}=\frac{\sum \mathrm{XY}}{\sum \mathrm{X}^{2}}
$$

Pengujian hipotesis kedua tentang faktor-faktor yang mempengaruhi tingkat produksi gula di PG. Wringin Anom Kabupaten Situbondo digunakan dengan analisis Cobb-Douglas, menurut Soekartawi (1995), digunakan rumus sebagai berikut:

$$
Y=a X_{1}^{b_{1}} X_{2}^{b_{2}} X_{3}^{b_{3}} X_{4}^{b_{4}} \ldots X_{n}^{b_{n}} e
$$

Pengujian secara keseluruhan faktorfaktor hasil produksi yang berpengaruh secara bersama-sama terhadap produksi gula dapat diformulasikan dengan analisis uji $\mathrm{F}$ sebagai berikut:

$$
\begin{aligned}
& F-\text { hitung } \\
& =\frac{\text { jumlah kuadrat tengah regresi }}{\text { jumlah kuadrat tengah sisa }}
\end{aligned}
$$

Pengujian seberapa jauh variabel $\mathrm{Y}$ yang disebabkan oleh variasi variabel $\mathrm{X}$ dapat dihitung nilai koefisien determinasi dengan formulasi sebagai berikut:

$$
\begin{aligned}
\text { Adjusted } \mathrm{R}^{2}= & 1-(1 \\
& \left.-R^{2}\right) \frac{N-1}{(N-K-1)}
\end{aligned}
$$

$\mathrm{N}=$ jumlah contoh (sampel yang diambil) $\mathrm{k}=$ banyaknya parameter

Pengaruh masing-masing koefisien regresi dapat diketahui melalui uji-t dengan formulasi sebagai berikut:

$$
t-\text { hitung }=\left|\frac{b_{i}}{S b_{i}}\right|
$$

$$
\mathrm{Sb}_{\mathrm{i}}=\sqrt{\frac{\text { Jumlah Kuadrat Sisa }}{\text { Jumlah Kuadrat Tengah Sisa }}}
$$

$b_{i} \quad=$ Koefisien regresi ke-i

$\mathrm{Sb}_{\mathrm{i}} \quad=$ Standart deviasi ke- $\mathrm{i}$

Berdasarkan hipotesis ketiga yaitu mengenai tingkat efisiensi biaya pada PG. 
Jurnal Agribest Vol 01 No 02, September 2017: 116-124

Wringin Anom Kabupaten Situbondo, digunakan analisis RC-ratio dengan formulasi sebagai berikut (Soekartawi, 1995):

$$
\mathrm{RC}-\text { ratio }=\frac{\text { total penerimaan }(\mathrm{Rp})}{\text { total biaya }(\mathrm{Rp})}
$$

\section{HASIL PENELITIAN DAN PEMBAHASAN}

\section{Trend Luas Lahan Tebu, Produksi danProduktivitas Gula}

Persamaan garis trend luas lahan tebu yang diperoleh dari hasil analisis menggunakan metode trend adalah: $\mathbf{Y}=$ 1.699,20 $+4,45$ X. Persamaan ini menunjukkan besarnya nilai koefisien trend Tabel 1. Perkiraan Perkembangan Luas Lahan Tebu Di PG. Wringin Anom Situbondo Tahun 2016-2021

\begin{tabular}{cccc}
\hline Tahun & A & B & Trend Luas Lahan (ha) \\
\hline 2016 & $1.699,20$ & 4,45 & 1734,80 \\
2017 & & & 1739,25 \\
2018 & & & 1743,70 \\
2019 & & & 1748,15 \\
2020 & & & 1752,60 \\
\hline
\end{tabular}

Sumber:Analisis Data Sekunder (diolah 2016).

Berdasar Tabel 1diperkirakan luas lahan tebu PG. Wringin Anom Kabupaten Situbondo dari tahun 2016-2020 mengalami kenaikan. Hal ini ditunjukkan dengan luas lahan pada tahun 2020 mencapai angka 1.752,60 ha, sedangkan tahun 2016 hanya 1.734,80ha. Hasil trend luas lahan tebu memiliki trendmeningkat atau positif. Perkembangan luas lahan tebu tersebut dapat digunakan dengan asumsi jika keadaan pada saat ini hampir sama dengan keadaan mendatang.

Hasil analisis terhadap data produksi menggunakan metode trendmenghasilkan persamaan garis trend produksi gula berikut:Y $=104091,92+1225,6 \mathrm{X}$. Persamaan ini menunjukkan besarnya nilai sebesar 4,45 yang artinya besarya penambahan luas lahan tebu tiap tahunnya sebesar 4,45 dan intersep atau konstanta yang didapatkan sebesar 1.699,20yang artinya rata-rata luas lahan tebu selama 15 tahun terakhir yang dikelola oleh PG. Wringin Anom Kabupaten Situbondo sebesar $1.699,20$ hektar.

Perkembangan luas lahan tebu di PG. Wringin Anom Kabupaten Situbondo pada tahun yang akan datang dapat diperkirakan dengan mengetahui trend luas lahan tebu. Perkiraan luas lahan tebu dilakukan selama 5 tahun mendatang yaitu tahun 2016-2021 sebagaimana yang disajikan pada Tabel 1. koefisien trend sebesar 1.225,6 yang artinya besarya penambahan produksi gula tiap tahunnya sebesar 1.225,6 kuintal dan intersep yang didapatkan sebesar 104.091 yang artinya rata-rata hasil produksi gula selama 15 tahun terakhir yang dihasilkan oleh PG. Wringin Anom sebesar 104.091,92 kuintal. Adapun perkiraan produksi gula dilakukan selama 5 tahun mendatang yaitu tahun 20162020disajikan dalam Tabel 2 berikut: 
Tabel 2. Perkiraan Produksi Gula Pada PG. Wringin Anom Situbondo Tahun 2016-2020

\begin{tabular}{cccc}
\hline Tahun & A & b & Trend Produksi (ku) \\
\hline 2016 & $104.091,92$ & $1.225,6$ & 113896,72 \\
2017 & & & 115122,32 \\
2018 & & & 116347,92 \\
2019 & & & 117573,52 \\
2020 & & & 118799,12 \\
\hline
\end{tabular}

Sumber:Analisis Data Sekunder (diolah 2016)

Tabel 2 memperkirakan bahwa produksi gula PG. Wringin Anom Kabupaten Situbondo dari tahun 2016-2020 mengalami kenaikan produksi. Hal ini ditunjukkan dengan jumlah produksi gula pada tahun 2020 mencapai 118.799 kuintal atau memiliki trend yang meningkat atau positif. Perkembangan produksi gula tersebut dapat digunakan dengan asumsi jika keadaan pada saat ini hampir sama dengan keadaan mendatang.

Persamaan garis trend produktivitas gula yang diperoleh dari hasil analisis menggunakan metode trend adalah: $\mathbf{Y}=\mathbf{6 1 , 2}$

+ 0,6 X. Persamaan ini menunjukkan besarnya nilai koefisien trend sebesar 0,6 yang artinya besarya penambahan produktivitas gula tiap tahunnya sebesar 0,6 kuintal dan intersep yang didapatkan sebesar 61,2 yang artinya rata-rata produktivitas gula PG. Wringin Anom Kabupaten Situbondo selama 15 tahun terakhir oleh sebesar 61,2 $\mathrm{ku} / \mathrm{ha}$.

Perkiraan produktivitas gula dilakukan selama 5 tahun mendatang yaitu tahun 20162020. Perkembangan produktivitas gula pada PG. Wringin Anom Kabupaten Situbondo lima tahun mendatang disajikan dalam Tabel 3 berikut.

Tabel 3. Perkembangan Produktivitas Gula Pada PG. Wringin Anom Tahun 2016-2020

\begin{tabular}{cccc}
\hline Tahun & A & B & Trend Produktivitas (ku/ha) \\
\hline 2016 & 61,2 & 0,6 & 66,00 \\
2017 & & & 66,60 \\
2018 & & & 67,20 \\
2019 & & & 67,80 \\
2020 & & & 68,40 \\
\hline
\end{tabular}

Sumber:Analisis Data Sekunder (diolah 2016).

Tabel 3 menjelaskan bahwa perkiraan produktivitas gula PG. Wringin Anom Kabupaten Situbondo dari tahun 2016-2020 mengalami kenaikan atau memiliki trend yang meningkat atau positif. Perkembangan produktivitas gula tersebut dapat digunakan dengan asumsi jika keadaan pada saat ini hampir sama dengan keadaan mendatang. 


\section{Faktor-Faktor yang Mempengaruhi Produksi Gula}

Analisis faktor-faktor yang mempengaruhi produksi gula di PG. Wringin Anom Kabupaten Situbondo dilakukan dengan menggunakan pendekatan Cobb-Douglas, dimana produksi gula (ku/ha) merupakan variabel terikat/dependent variable $(\mathrm{Y})$, sedangkan luas lahan tebu $\left(\mathrm{X}_{1}\right)$, bobot tebu $\left(\mathrm{X}_{2}\right)$, rendemen $\left(\mathrm{X}_{3}\right)$ dan tenaga kerja $\left(\mathrm{X}_{4}\right)$ sebagai variabel bebas/independent variable. Aplikasi yang digunakan adalah SPSS 16 dengan metode stepwise. Metode stepwisemerupakan salah satu metode untuk mendapatkan model terbaik dari sebuah analisis regresi, secara definisi adalah gabungan antara metode forward dan backward, variabel bebas yang pertama kali masuk adalah variabel yang korelasinya

tertinggi dan significant dengan variabel terikat.

Tabel 4. Hasil Analisis Regresi Fungsi Produksi GulaModel Stepwisedi PG. Wringin Anom

\begin{tabular}{|c|c|c|c|c|c|}
\hline Variabel & Parameter & B & Std. Error & $\mathbf{t}$ & Sig. \\
\hline (Constant) & $\beta_{0}$ & $-1,986$ & 0,007 & -297.076 & 0,000 \\
\hline Bobot Tebu (X2) & $\beta_{2}$ & 0,999 & 0,001 & 10870,175 & 0,000 \\
\hline Rendemen (X3) & $\beta_{3}$ & 0,997 & 0,001 & 896.912 & 0,000 \\
\hline Tenaga Kerja (X4) & $\beta_{4}$ & $-0,001$ & 0,001 & $-20,380$ & 0,037 \\
\hline Korelasi Berganda & $R$ & 1,000 & & & \\
\hline R Square & $R^{2}$ & 1,000 & & & \\
\hline Adjusted R Square & $\bar{R}^{2}$ & 1,000 & & & \\
\hline Std. Error of the Est. & se & 0,00016 & & & \\
\hline $\mathrm{F}$ & & $5,914 \mathrm{E} 5$ & & & 0,000 \\
\hline $\mathrm{N}$ & & 15 & & & \\
\hline
\end{tabular}

Sumber: Analisis Data Sekunder (diolah 2016).

Hasil analisis regresi menjelaskan bahwa variabel luas lahan perlu dibuang sebagai predictor dan metode yang digunakan adalah stepwise. Nilai F-hitung sebesar59,115 dengan tingkat signifikansi 0,000 menunjukkan bahwa secara keseluruhan variabel bebas kecuali luas lahan (bobot tebu, rendemen dan tenaga kerja) berpengaruh nyata terhadap variabel terikat yaitu tingkat produksi gula di PG. Wringin Anom Kabupaten Situbondo.
Uji Adjusted $\mathrm{R}^{2}$ disajikan pula dalam Tabel 5 sebesar1,000artinya $99 \%$ variabel terikat (produksi gula) dapat dijelaskan oleh seluruh variabel bebasnya, sedangkan sisannya $1 \%$ dijelaskan oleh sebab-sebab yang lain diluar model. 
Tabel 5. Hasil Analisis Regresi Fungsi Produksi Gula Full-Model diPG. Wringin Anom

\begin{tabular}{lcrrrr}
\hline \multicolumn{1}{c}{ Variabel } & Parameter & \multicolumn{1}{c}{ B } & Std. Error & \multicolumn{1}{c}{ t } & \multicolumn{1}{c}{ Sig. } \\
\hline Constant) & $\beta_{0}$ & $-1,984$ & 0,007 & $-265,105$ & 0,000 \\
Luas Lahan (X1) & $\beta_{1}$ & 0,001 & 0,002 & 0,547 & 0,596 \\
Bobot Tebu (X2) & $\beta_{2}$ & 0,998 & 0,002 & 592,852 & 0,000 \\
Rendemen (X3) & $\beta_{3}$ & 0,996 & 0,001 & 764,481 & 0,000 \\
Tenaga Kerja (X4) & $\beta_{4}$ & $-0,001$ & 0,001 & $-2,367$ & 0,039 \\
Korelasi Berganda & $R$ & 1,000 & & & \\
R Square & $R^{2}$ & 1,000 & & & \\
Adjusted R Square & $\bar{R}^{2}$ & 1,000 & & & \\
Std. Error of the Est. & $\mathrm{se}$ & 0,00017 & & & 0,000 \\
\hline $\mathrm{F}$ & \multicolumn{7}{c}{$153 \mathrm{E} 5$} & & \\
\hline $\mathrm{N}$ & & 15 & & & \\
\hline
\end{tabular}

Sumber: Analisis Data Sekunder (diolah 2016)

Persamaan fungsi produksi gula di PG.

Wringin Anom Kabupaten Situbondo adalah: $\log \mathrm{Y}=-1.984+0,001 \log \mathrm{X}_{1}+0,998 \log \mathrm{X}_{2}$ $+0,996 \log \mathrm{X}_{3}-0,001 \mathrm{X}_{4}$ dan dinyatakan sebagai fungsi produksi Cobb-Douglas sebagai berikut:

$$
Y=0,137 X_{1}^{0,001} X_{2}^{0,998} X_{3}^{0,996} X_{4}^{-0,001}
$$

Keterangan:

$$
\begin{array}{ll}
\mathrm{Y} & =\text { Produksi Gula }(\mathrm{ku}) \\
\mathrm{X}_{1} & =\text { Luas Lahan }(\mathrm{ha}) \\
\mathrm{X}_{2} & =\text { Bobot Tebu }(\mathrm{ku}) \\
\mathrm{X}_{3} & =\text { Rendemen }(\%) \\
\mathrm{X}_{4} & =\text { Tenaga Kerja (orang) } \\
\mathrm{e} & =\text { Variabel Pengganggu }
\end{array}
$$

Dari persamaan produksi tersebut maka dapat dijelaskan pengaruhmasingmasing variabel bebas terhadap produksi gula di PG. Wringin Anom sebagai berikut:

\section{Faktor Luas Lahan Tebu $\left(\mathrm{X}_{1}\right)$}

Faktor luas lahan tebu berdasarkan hasil analisis regresi Cobb-Douglas fungsi produksi gula model stepwiseadalah variabel yang perlu dihilangkan atau tidak berpengaruh secara nyata terhadap variabel terikat. Hal ini menunjukkan bahwa luas lahan tebu terhadap produksi gula di PG. Wringin Anom dapat mengakibatkan penurunan produksi karena peningkatan luas lahan yang tidak diikuti dengan efisiensi usahatani.

\section{Faktor Bobot Tebu $\left(\mathrm{X}_{2}\right)$}

Nilai koefisien regresi bobot tebu $\left(\mathrm{X}_{2}\right)$ adalah 0,999 yang berarti setiap penambahan $1 \%$ bobot tebu akan meningkatkan produksi gula sebesar0,999\% apabila faktor lain dianggap konstan. Hasil uji-t menunjukkan bahwa nilai signifikansi dari variabel bobot tebu adalah 0,000 yang berarti variabel bobot tebu $\left(\mathrm{X}_{2}\right)$ berpengaruh secara nyata terhadap produksi gula.Hal ini menunjukkan bahwa semakin besar bobot tebu yang digiling maka semakin meningkathasil produksi gula.

\section{Faktor Rendemen (X3)}

Berdasarkan nilai koefisien regresi nilai rendemen $\left(\mathrm{X}_{3}\right)$ sebesar 0,997 yang berarti setiap penambahan $1 \%$ rendemen tebu 
akan meningkat produksi sebesar 0,997\% dengan asumsi variabel-variabel lain dianggap konstan. Hasil uji-t menunjukkan bahwa nilai signifikansi dari variabel rendemen adalah 0,000 yang berarti variabel rendemen $\left(\mathrm{X}_{3}\right)$ berpengaruh nyata terhadap peningkatan produksi gula di PG. Wringin Anom. Hal ini dikarenakan semakin besar nilai rendemen tebu, maka semakin besar kandungan gula tebu, sehingga akan meningkatkan produksi gula.

\section{Faktor Tenaga Kerja $\left(\mathrm{X}_{4}\right)$}

Nilai koefisien regresi untuk variabel tenaga kerja $\left(\mathrm{X}_{4}\right)$ adalah sebesar $-0,001$ yang berarti setiap penambahan $1 \%$ tenaga kerja akan menurunkan produksi gula di PG. Wringin Anom sebesar0,001\%dengan asumsi variabel-variabel lain dianggap konstan. Hal ini berarti penggunaan tenaga kerja sudah terlalu banyak. Hasil uji-t menunjukkan bahwa nilai signifikansi dari variabel tenaga kerja adalah 0,037 yang berarti variabel tenaga kerja $\left(\mathrm{X}_{4}\right)$ berpengaruh secara nyata terhadap produksi gula akan tetapi berpengaruh negatif.

\section{c. Efisiensi Biaya di PG. Wringin Anom}

Effisiensi penggunaan biaya dapat diukur drai ratio penerimaan dan biaya.
Sehingga perusahaan dikatakan efisien dalam hal penggunaan biaya jika dapat mengatur keuangannya sehingga setiap pengeluaran biaya dapat menghasilkan penerimaan yang sebesar-besarnya.

Hasil analisis R-C ratio mengetahui tingkat efisiensi biaya hasil produksi PG. Wringin Anom disajikan pada Tabel 6 . Penerimaan didapat dari penjualan gula dan tetes. Penjualan gula dilakukan oleh pabrik kepada karyawan atas haknya, maupun melalui kantor Direksi PTPN XI di Surabaya dan tetes dijual kepada mitra perusahaan yang sudah terikat sebelumnya. Tabel 6 menunjukkan bahwa PG. Wringin Anom pada kurun waktu 2010-2015 mengalami efisiensi biaya pada tahun 2011, 2012, 2014 dan 2015 dengan efisiensi biaya tertinggi tahun 2012 dengan nilai RC-ratio sebesar 1,208 yang diiringi keuntungan tertinggi sebesar Rp9.524.266.951. Sedangkan pada tahun 2010 dan 2013 mengalami inefisiensi biaya dan tingkat inefisiensi biaya terendah tahun 2010 dengan nilai RC-ratio sebesar 0,883 dan kerugian mencapai $\mathrm{Rp}$ 4.145.782.167. 
Tabel 6. Total Penerimaandan Total Biaya Produksi PG Wringin Tahun 2010-2015.

\begin{tabular}{ccccc}
\hline Tahun & $\begin{array}{c}\text { Total Penerimaan } \\
(\mathbf{R p})\end{array}$ & Total Biaya (Rp) & Laba/Rugi (Rp) & RC-Ratio \\
\hline 2010 & 31.209 .479 .700 & 35.355 .261 .867 & $(4.145 .782 .167)$ & 0,883 \\
2011 & 43.224 .076 .950 & 37.709 .320 .502 & 5.514 .756 .448 & 1,146 \\
2012 & 55.265 .888 .050 & 45.741 .621 .099 & 9.524 .266 .951 & 1,208 \\
2013 & 51.430 .266 .370 & 52.334 .878 .261 & $(904.611 .891)$ & 0,983 \\
2014 & 57.160 .382 .200 & 56.825 .552 .078 & 334.830 .722 & 1,006 \\
2015 & 57.133 .769 .920 & 54.432 .172 .312 & 2.701 .597 .608 & 1,050 \\
\hline Rata-Rata & $\mathbf{3 3 . 0 1 3 . 5 3 2 . 5 9 3}$ & $\mathbf{4 7 . 0 6 6 . 4 6 7 . 6 8 7}$ & $\mathbf{1 4 . 1 8 6 . 9 4 5 . 5 1 9}$ & $\mathbf{1 , 0 4 6}$ \\
\hline
\end{tabular}

Sumber: Laporan Evaluasi Giling PG. WringinAnom diolah(2016).

\section{KESIMPULAN}

1. Perkembangan luas lahan, produksi dan produktivitas gula di PG. Wringin Anom dari tahun 2001-2015 memiliki trend yang meningkat.

2. Faktor-faktor yang berpengaruh secara signifikan terhadap produksi gula yaitu: bobot tebu, rendemen dan tenaga kerja sedangkan faktor luas lahan tidak berpengaruh secara nyata terhadap produksi gula di PG. Wringin Anom Kabupaten Situbondo.

3. Efisiensi biaya dari tahun 2010-2015 PG. Wringin Anom Kabupaten Situbondo menunjukkan tingkat efisien kecuali pada tahun 2010 dan 2013 mengalami inefisiensi

\section{DAFTAR PUSTAKA}

Disbun Jatim. 2011. Perkembangan Areal, Produksi, Produktivitas dan Rendemen Tebu di Propinsi Jawa Timur Tahun 2009-2010. www.disbun.jatimprov.go.id.

Diakses pada tanggal 18 November 2016.

Hafsah, M. J. 2002. Bisnis Gula di Indonesia. Jakarta: Pustaka Sinar Harapan.

Nazir, M. 1999. Metode Penelitian. Jakarta: Ghalia.

Soekartawi. 1995. Agribisnis Teori dan Aplikasinya - cetakan pertama. Jakarta: PT Raja Grafindo Persada.

Supranto,J.M.A. 2000. Statistik : Teori dan Aplikasi.Jakarta:Erlangga.

Suwandi, A. 2015. Transformasi Industri Gula. Surabaya. XI News. 